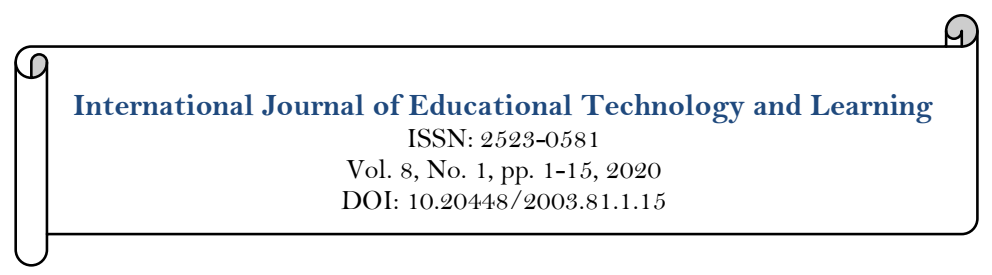

updates

\title{
Degree of Educational Portal Use in the Schools of the Future from its Teachers' Perspective
}

\author{
Hamzah Mahmoud Daradkah
}

Ph.D. in Educational Technology Ministry of Education, Kingdom of Bahrain. Email:daradkahhamzah@gmail.com

\begin{tabular}{|c|c|}
\hline Abstract & \\
\hline $\begin{array}{l}\text { The aim of this paper is to reveal the degree of educational portal use in His } \\
\text { Majesty King Hamad's project for schools of the future from its teachers' } \\
\text { perspective in the light of gender variable, qualification variable, variable of } \\
\text { experience in teaching, and training courses variable. To achieve the above- } \\
\text { mentioned purpose, a questionnaire was designed meticulously and was } \\
\text { validated before use. The research sample was composed of } 340 \text { teachers, } \\
\text { randomly selected from the teachers of His Majesty King Hamad's Project } \\
\text { for Future Schools in the Kingdom of Bahrain. The results of the study } \\
\text { showed a high degree of the educational portal use in His Majesty King } \\
\text { Hamad's project for schools of the future from its teachers' perspective. The } \\
\text { results indicated that there are no statistically significant differences at the } \\
\text { significance level of ( } \alpha \leq \text { o.O5) between the sample estimates for the degree of } \\
\text { educational portal use as a system for e-learning management in future } \\
\text { schools attributed to the variables of gender and experience in teaching, } \\
\text { while there are statistically significant differences attributable to } \\
\text { qualification variable, training courses and the interaction between them. } \\
\text { The study recommended the necessity of holding more courses and training } \\
\text { workshops on how to employ the educational portal in various educational } \\
\text { and administrative aspects, the necessity of providing teacher's Guides that } \\
\text { explain how to use the educationalportal in the educationalprocess. }\end{array}$ & $\begin{array}{l}\text { Licensed: } \\
\text { This work is licensed under a } \\
\text { Creative Commons Attribution } 4.0 \\
\text { License. } \\
\text { Publisher: } \\
\text { Scientific Publishing Institute } \\
\text { Accepted: } 21 \text { January } 2020 \\
\text { Published: } 3 \text { February } 2020\end{array}$ \\
\hline
\end{tabular}

Funding: This work was supported by Ministry of Education, Kingdom of Bahrain.

Competing Interests: The author declare that they have no competing interests.

\section{Introduction}

The present era is witnessing a technological change in various fields and a rapid development in the field of knowledge. The proliferation of Internet networks and information systems development and their applications have prompted educational institutions to develop their policies, systems, and the way services are rendered and delivered to beneficiaries. So, most of the educational institutions have relied on Internet applications, e-learning management systems, in achieving their goals, and completing their work.

Digital learning develops learners' ability to self-manage, raise their awareness by interchanging ideas, information, and opinions, develop creative thinking and higher-level thinking by employing problem-solving skill that is based on digital and multimedia tools used in creativity, imagination and gain experiences (Zein, 2016). Amer (2017) defined digital learning elements as small educational parts made up of video, audio, still and moving pictures, and texts stored inside a specific place called a digital repository, so that it can be retrieved, used, utilized and reused again. Brian (2005) defined it as a dataset that has been saved, classified, and collected in digital content for reuse in e-learning systems.

Designing, creating e-lessons and preparing digital content is extremely important, where it relies on a new approach based on Learning Objects, a form of technological development in the field of e-learning that is published via the Internet, which can be reused in different educational situations according to the 
requirements of the educational position and help to enrich the educational position and achieve its goals. In view of the foregoing, the development of electronic content using digital learning objects has become a major requirement for designing E-curriculum and producing high-quality instructional materials that contribute effectively to taking into account individual differences between learners, improving educational outcomes, working on cost-reduction, and time required to produce high-quality educational materials (Salem, 2004). The role of digital empowerment appears in teaching practices through the use of digital learning objects stored in an integrated learning environment that allows learners to use the appropriate multimedia (text, audio, images, video, animation) according to the e-learning management system and providing good scientific content that contributes to engaging learners, motivating them to learn, encouraging cooperation among them, providing feedback and promoting active-learning (Al-Jerioui, 2014).

\subsection{Theoretical Framework}

In light of the continuous development of e-learning methods, most educational institutions have tended to use educational portals based on e-learning management systems that are considered one of the technological media in the process of educational communication and improving the teaching and learning processes (Abu Rayan, 2017). The educational portals carry out administrative and academic work that requires advance preparation and ongoing training to face administrative, technical, and material challenges (Hamayel \& Hamayel, 2006).

The newly started educational portals are used as an effective technology in activating the role of educational institutions and linking them with each other and with the relevant local community. This technology relies mainly on information and communication technologies capable of storing, updating, and exchanging knowledge dynamically. The main goal of educational portals is to create an interactive-learning environment that entrenches work as a social concept and provides opportunities for interaction and communication between different educational communities (Othman, 2010).

The educational portal has emerged as an e-learning management system that links all the elements of the educational process electronically (the teacher, the student, the guardian, the school administration) through a set of programs and services that are included using the Internet, which made the use of an educational portal a useful way to achieve communication between the various elements of the educational process. Therefore, the design of educational portals requires their suitability for the level of their users, students, teachers and researchers in terms of the amount of information provided, the level of language used, the suitability of the method for displaying texts and graphics, the method of browsing the site, and the availability of requirements for using the portal from hardware and software. The design of the portal must take into account the type and speed of communication through the local network or the Internet through which the service is provided (Sadiq, 2012). (Pima, 2013) defines the educational portal as a website on the Internet that aims to provide the beneficiaries with the information and resources needed to access the systems and information they need in their field of work to increase productivity. Sadiq (2012) defines it as an educational website designed to help teachers and students access the required educational resources by applying and displaying them according to their goals and the quality of their contents to their users to access the required information with the least time and effort possible.

Hence, the Ministry of Education in the Kingdom of Bahrain was keen to implement the educational portal project by employing advanced science-based technologies in developing the educational process and providing an electronic network that allows for rapid information transfer, exchange of ideas, opinions and experiences in various aspects of the educational process and enhancing quality in the educational process by providing interactive education based on the use of modern tools and techniques, providing an opportunity for selflearning for students outside the school, and linking the largest possible number of the Ministry's audience, including teachers, students, parents, and school administrations.

It is worth noting that there are many studies that dealt with the degree of using the educational portal in the-learning process and teachers' perceptions towards its use such as those by Al-Hinai (2011); Al-Sawaei (2010); Hsia and Tseng (2016); Mahmud, Ismail, Rahman, Kamarudin, and Ruslan (2012); Pynoo and van Braak (2014); Miri and Sahu (2019); Al-Ameri (2010); Dakhil (2014).

Miri and Sahu (2019) conducted a study aimed at exploring users' perceptions of the educational portal in the higher secondary education sector in India. The results indicated that teachers and students' perceptions were positive towards the educational portal and that the educational portal provides good study materials that contribute to improving the quality of teaching and learning and provide an opportunity for self-learning.

In a study conducted by Hsia and Tseng (2016) which aimed to adopt a theoretical model that affects primary school teachers on the use of the educational portal by incorporating personal traits (conscience, openness, extroversion), it was found that the personal characteristics of conscience and openness to experience affect teachers 'desire to use the educational portal positively through the use of the educational portal to exchange educational materials and improve the effectiveness of teaching and that teachers who have positive beliefs about learning and searching for knowledge and educational materials using the educational portal lead to an in-depth and advanced education compared to teachers who have negative beliefs about using the educational portal. The sample for the study consisted of (512) teachers in (25) primary schools in Taiwan. 
Pynoo and van Brak (2014) conducted a study aimed at exploring teachers' perceptions towards the actual use of the educational portal according to the gender variable. The study sample consisted of (864) teachers. The results indicated that the teachers' attitudes were positive towards the use of educational portal, and that there are few differences between Male and female, as the female attitude was more positive towards using educational portal and they have a stronger desire to use it.

Dakhil (2014) conducted a study aimed at exploring the degree of the contribution of the application of the Noor e-learning management system in education schools (boys / girls) in Shaqra Governorate to improving the administrative process from the viewpoint of its managers. The sample consisted of (73) male and female managers. The results indicated that the application of the Noor system was of moderate degree in the areas of availability of human and technical requirements for the Noor system and the services of the beneficiaries, while the application of the Noor system was of low degree in the areas of awareness and media, The results also indicated that the application of the Noor system contributes significantly to improving the administrative process.

In a study conducted by Mahmud et al. (2012) 387 secondary school teachers from five states of Malaysia were selected at simple random. The study, which focused on determining the teachers 'preparations to use educational resources in the educational portal, found the majority of teachers were moderate users of the educational portal, and that the majority of teachers have positive attitudes towards using the educational portal in the educational process. The results also found that that most teachers lack the skills necessary to take full advantage of the online educational portal, which requires training them to use it.

Al-Hinai (2011) conducted a study aimed at identifying the "reality" of employing the electronic educational portal in the school administration in the Sultanate of Oman, the difficulties they face when applying and how to overcome them. The sample consisted of (60) principals from basic education schools in Muscat and Al Buraimi governorates. The results concluded that the educational portal is used to a high degree in the field of school administration, there are difficulties facing school administrations in employing the educational portal in school administration to a large extent. The results also found that there were no statistically significant differences attributable to the gender variable; administrative experience and qualification regarding the "reality" of educational portal use in school administration, there are statistically significant differences regarding the difficulties in using the educational portal due to the variable of the educational qualification. The study also found that there are statistically significant differences in the field of administrative and financial difficulties due to the gender variable in favour of males, there are statistically significant differences in the field of technical difficulties due to the gender variable, and there are statistically significant differences in the fields of difficulties in employing the educational portal in school administration in favour of administrative experience. The study recommended the need to increase the speed of the Internet in schools and provide schools with specialized technicians to maintain electronic devices in schools.

Othman (2010) study, aimed to define mechanisms for exchanging information between members of educational societies (students, teachers, officials, parents), assessment of use level and technical difficulties from the viewpoint of users of the educational portal. The sample consisted of 400 participants from teachers, students, administrators and parents in the secondary stage. The results showed that there is a great variation in the type of services used and the degree of their use by different groups in the study sample.

Ameri (2010) conducted a study aimed at developing a proposed vision for developing the educational portal in the Ministry of Education in the Sultanate of Oman in accordance with contemporary educational needs and standards. The total sample size was about 2000, and was composed of 105 administrative officials with (400) teachers, (500) students, and (500) parents. The study concluded that the e-learning should be included in the educational portal, the necessity of providing various educational and administrative services and educational activities for the student, and providing training and administrative services for teachers.

Al-Sawaei (2010) conducted a study aimed at revealing the degree of use of school teachers for the elearning portal and the difficulties they face in Muscat Governorate. The study sample consisted of (365) teachers from the Muscat Governorate schools. The results showed that the school teachers used the elearning portal at a medium degree. The results also showed that there were no statistically significant differences in the individual participants' responses attributable to the gender and specialty variable, while there are statistically significant differences attributable to experience variable. The study also found that the most prominent challenges faced by teachers in using the electronic learning portal are that the educational portal does not often respond the lack of services provided by the educational portal, and the lack of qualified staff in information technology by the Ministry of Education.

In a study conducted by Issham, Ramli, Rosli, and Idrus (2010) a sample of 1200 students were chosen. The study, which focused on assessing the satisfaction of the beneficiaries towards the e-learning portal in Distance-learning in Malaysia, found that planning for the design of the educational portal and its façade, font size and portal language, have a major impact on beneficiaries' satisfaction and interaction with the portal.

From the above, it is clear that the majority of prior research such as those by Miri and Sahu (2019); Hsia and Tseng (2016); Pynoo and van Braak (2014); Mahmud et al. (2012); Dakhil (2014) indicated that the teachers 'attitudes were positive towards using the educational portal in the educational process and it has a big role in improving it, whereas the studies by Hsia and Tseng (2016); Mahmud et al. (2012); Al-Hinai 
(2011); Othman (2010); Al-Sawaei (2010) also indicated the degree of use of the educational portal among teachers. While a study by Issham et al. (2010) has confirmed that the design of the educational portal, its façade, the font size and the language of the portal, significantly affect the satisfaction of the beneficiaries and their interaction with the electronic portal, Ameri (2010) emphasized the necessity of employing various educational and administrative services and educational activities. The study of Ameri (2010); Mahmud et al. (2012) emphasized the need to train teachers to use the educational portal to take full advantage of it. Based on previous studies, this study benefited from its predecessor in determining the current study's objectives, in preparing some elements of the theoretical framework, the design and preparation of the study tool. In explaining the study findings and comparing them with the findings in prior studies, this study is consistent with previous research on general goals and differs from some previous studies in terms of methodology, study procedures, and geographical space. To the best of the researcher's knowledge, no study was conducted at the level of the Kingdom of Bahrain that dealt with the subject of the current study. It also differs from previous studies as it aimed to reveal teachers 'perceptions towards the educational portal.

\subsection{Study Problem}

The Ministry of Education in the Kingdom of Bahrain has endeavoured to employ various technological technologies in the educational field through many projects. Among the most prominent is the educational portal project, which is one of the pioneering projects to keep pace with technological progress. The educational portal is an electronic window that provides its services to the beneficiaries of the entire educational system, including students, teachers, school administrations and parents, and to provide an opportunity for self-learning for students at any time and anywhere through access to the educational portal via the web or mobile devices.

The efforts made by the Ministry and its constant concern to develop and amend the services provided by the educational portal and provide the necessary training for teachers to use them has prompted school administrations to emphasize the necessity of employing the educational portal in the educational process and in communicating with students and parents. However, the researcher noticed, during his work in the ministry, the varying ability of teachers to use the educational portal and optimize it in the educational process in terms of exploiting the capabilities available in the educational portal in addition to a negative trend from some teachers towards using the educational portal.

To ensure this, the researcher conducted an exploratory study on a random sample of teachers from the basic stage teachers in order to verify the degree of their use of the educational portal in the educational process. The results showed the varying ability of teachers to make optimal use of the educational portal in the-learning process. Therefore, the current study sought to reveal the degree of educational portal use in His Majesty King Hamad's project for schools of the future from its teachers' perspective.

Therefore, the research problem can be summarized through the following main question: "What is the degree of educational portal use in His Majesty King Hamad's project for schools of the future from its teachers' perspective?"

\subsection{Significance of the study}

The Ministry of Education in the Kingdom of Bahrain has benefited from implementing the educational portal project by providing an electronic network that allows for rapid transfer and exchange of knowledge, information, ideas, and experiences for various aspects of the educational process, and providing a database that can be used to implement educational plans, programs, and projects. This orientation by the Ministry of Education is consistent with His Majesty King Hamad bin Isa. The importance of the current study is as follows:

- This study is one of the first studies in the Kingdom of Bahrain that seeks to reveal the teacher's degree of use for the educational portal as a system for e-learning management in His Majesty King Hamad's project for schools of the future from its teachers' perspective.

- The Ministry of Education officials benefited by the educational portal in identifying the technical, technical and human needs for the optimal use of the educational portal.

- Motivating the educational departments of the Ministry of Education to do what is necessary to develop the educational portal and facilitate its use.

- Enriching the applications of e-learning management systems in light of the Ministry's move towards a complete transition to digital education.

- Directing the attention of researchers to conduct further studies related to the use of the educational portal in the educational process in the Kingdom of Bahrain.

\subsection{Research Questions and Objectives}

The present study aims to:

- Measuring the degree of use for the educational portal as a system for e-learning management in His Majesty King Hamad's project for schools of the future from its teachers' perspective. 
- Measuring the teachers' perceptions of using the educational portal as an e-learning management system in His Majesty King Hamad's project for future schools from its teachers' perspective.

- To study the goal of this problem, the research requires answering the following main questions:

1. What is the degree of use for the educational portal as a system for e-learning management in His Majesty King Hamad's project for schools of the future from its teachers' perspective?

2. Are there statistically significant differences at the level of significance $(\alpha \leq 0.05)$ to the degree of use for the educational portal as a system for e-learning management in His Majesty King Hamad's project for schools of the future according to the difference of gender variable, qualification variable, variable of experience in teaching, training courses variable, and interaction between them?

3. What are teachers' perceptions of using the educational portal as a system for managing e-learning in His Majesty King Hamad's Project for Future Schools?

4. Are there statistically significant differences at the level of significance $(\alpha \leq 0.05)$ of teachers 'perceptions towards the use of the educational portal as an e-learning management system in His Majesty King Hamad's project for future schools according to the difference of gender variable, qualification variable, variable of experience in teaching, training courses variable, and interaction between them?

\section{Study Methodology}

This study relies on the descriptive approach, in order to describe the problem and determine its causes through access to previous Arab and foreign literature and studies related to the study. The same approach was followed in preparing the study tool to reveal the degree of educational portal use in His Majesty King Hamad's project for schools of the future from its teachers' perspective.

\subsection{Study Sample}

The researcher selected a random sample from the teachers of His Majesty King Hamad's project for future schools in the Kingdom of Bahrain and distributed the study tool to them using Google Forms. 340 teachers from future schools in the Kingdom of Bahrain during the second semester of the academic year 2018/2019 were selected as the sample population for the study. Table 1 shows the distribution of the study sample according to its variables.

Table-1. Repetitions and proportions of the study sample according to its independent variables.

\begin{tabular}{|c|c|c|c|c|}
\hline Variable & Variable's levels & No & $\%$ & Total \\
\hline \multirow[t]{2}{*}{ Gender } & Male & 160 & 47.1 & \multirow{2}{*}{340} \\
\hline & Female & 180 & 52.9 & \\
\hline \multirow[t]{2}{*}{ Qualification } & Bachelor & 195 & 57.4 & \multirow{2}{*}{340} \\
\hline & Postgraduate & 145 & 42.6 & \\
\hline \multirow[t]{3}{*}{ Experience in teaching } & Less than 5 years & 90 & 26.5 & \multirow{3}{*}{340} \\
\hline & $5-10$ years & 109 & 32.1 & \\
\hline & More than 10 years & 141 & 41.5 & \\
\hline \multirow[t]{3}{*}{ Training courses } & I did not attend any course & 106 & 31.2 & \multirow{3}{*}{340} \\
\hline & From $1-3$ courses & 138 & 40.6 & \\
\hline & More than 3 courses & 96 & 28.2 & \\
\hline
\end{tabular}

Source: Data processed (2019).

\subsection{Research Hypotheses}

- There is a statistically significant difference at the level of significance $(\alpha \leq 0.05)$ to the degree of use for the educational portal as a system for e-learning management in His Majesty King Hamad's project for schools of the future according to the difference of gender variable, qualification variable, variable of experience in teaching, training courses variable, and interaction between them.

- There is a statistically significant difference at the level of significance $(\alpha \leq 0.05)$ of teachers 'perceptions towards the use of the educational portal as an e-learning management system in His Majesty King Hamad's project for future schools according to the difference of gender variable, qualification variable, variable of experience in teaching, training courses variable, and interaction between them.

\subsection{Study Procedures}

After confirming the psychometric properties of the study instrument, approval was obtained from the Department of Scientific Research at the Ministry of Education in the Kingdom of Bahrain to distribute the questionnaire to teachers who were randomly chosen from the King's Schools. The questionnaire was distributed in the form of an electronic link that was constructed using Google Forms for the 20 school administrations in order to generalize the link to the school's teachers. The total number of teachers who answered the questionnaire was 340 . 


\subsection{Study Tool}

To achieve the above-mentioned purpose, a questionnaire was designed meticulously and was validated before use. The questionnaire was divided into three sections. Section 1 covered the personal data, including variables of gender, educational qualification, experience in teaching, and training courses. Section 2 surveyed the extent to which the educational portal is used in His Majesty King Hamad's project for schools of the future. Section 3 included teachers' attitudes towards the use of the educational portal of His Majesty King Hamad's project for future schools. The questionnaire included five levels of performance and the scale used on the questionnaire is very high, high, medium, few, and very few. Placing Scores were distributed according to the following estimation method in Table 2.

Table-2. Quantitative assessment of performance levels and regular statistical ranking.

\begin{tabular}{c|c|c|c|c}
\hline \multicolumn{3}{c}{ Level of performance } \\
\hline Very High & High & Medium & Few & Very few \\
\hline 5 & 4 & 3 & 2 & 1 \\
\hline 5.00-3.67 & $3.66-2.34$ & \multicolumn{2}{c}{$2.33-1.00$} \\
\hline Big & Medium & Few \\
\hline
\end{tabular}

\subsection{Validity and Reliability of the Tool}

To verify the suitability of the study tool, wording, clarity, inclusiveness, and coherent, the study was presented to 10 arbitrators and specialists in the field of educational technology. The arbitrators, who made some changes to the study tool, agreed on the suitability of the tool to reveal the degree of educational portal use in His Majesty King Hamad's project for schools of the future from its teachers' perspective.

In this study, the internal consistency was measured by calculating the Pearson correlation coefficient to determine the extent to which the items in each axis are related to the overall degree. The analysis showed that the correlation between the axes is statistically significant at the level of significance 0.01, which indicates that the tool has a high degree of honesty (Table 3).

Table-3. Pearson correlation coefficient for items measuring the degree of use of the educational portal.

\begin{tabular}{|c|c|c|c|}
\hline Item & $\mathbf{R}$ & Item & $\mathbf{R}$ \\
\hline $\begin{array}{l}\text { See instructions from the } \\
\text { school administration. }\end{array}$ & $.499(* *)$ & $\begin{array}{l}\text { Add projects and educational experiences } \\
\text { for various subjects. }\end{array}$ & $.540(* *)$ \\
\hline $\begin{array}{l}\text { See the calendar and its } \\
\text { announcements and bulletins. }\end{array}$ & $.671(* *)$ & $\begin{array}{l}\text { Adding the weekly study schedule for } \\
\text { subjects. }\end{array}$ & $.312(* *)$ \\
\hline $\begin{array}{l}\text { Read circulars and internal } \\
\text { communications issued by the } \\
\text { school administration. }\end{array}$ & $.643(* *)$ & $\begin{array}{l}\text { Adding the weekly newsletter to the } \\
\text { subjects to be learned for various subjects. }\end{array}$ & $.190(* *)$ \\
\hline $\begin{array}{l}\text { Download textbooks for } \\
\text { various subjects. }\end{array}$ & $.339(* *)$ & $\begin{array}{l}\text { Publish special announcements by the } \\
\text { teacher regarding the educational process. }\end{array}$ & $.656(* *)$ \\
\hline $\begin{array}{l}\text { Download educational guides } \\
\text { for various educational stages. }\end{array}$ & $.631(* *)$ & $\begin{array}{l}\text { Monitor the attendance and absence of } \\
\text { students for different grades. }\end{array}$ & $.459(* *)$ \\
\hline $\begin{array}{l}\text { Add e-lessons for various } \\
\text { subjects. }\end{array}$ & $.701(* *)$ & $\begin{array}{l}\text { Communicate with students and their } \\
\text { parents regarding the educational process. }\end{array}$ & $.516(* *)$ \\
\hline $\begin{array}{l}\text { Add training activities for } \\
\text { students to the subjects } \\
\text { studied. }\end{array}$ & $.715(* *)$ & $\begin{array}{l}\text { Communicate with the school portal } \\
\text { administrator to solve technical problems. }\end{array}$ & $.514(* *)$ \\
\hline $\begin{array}{l}\text { Add discussion panels for } \\
\text { students to the topics learned. }\end{array}$ & $.654(* *)$ & Modify and update user profile. & $.531(* *)$ \\
\hline $\begin{array}{r}\text { educational } \\
\text { in } \quad \text { various } \\
\end{array}$ & $.451(* *)$ & & \\
\hline
\end{tabular}

To verify the reliability of the tool, the Cronbach alpha coefficient was calculated for the internal consistency between the items of the study instrument (Table 4). Its value was (0.82). This percentage was considered suitable for the purposes of the study for which it was designed. 
Table-4. Pearson correlation coefficient of items measuring teachers' perceptions towards the educational portal.

\begin{tabular}{|c|c|c|c|}
\hline Item & $\mathbf{R}$ & Item & $\mathbf{R}$ \\
\hline $\begin{array}{l}\text { The contents of the educational portal are clear } \\
\text { on the home page. }\end{array}$ & $.445\left(^{* *}\right)$ & $\begin{array}{l}\text { All components of the-learning Portal } \\
\text { have a high level of protection and } \\
\text { privacy. }\end{array}$ & $.285\left(^{(* *}\right)$ \\
\hline $\begin{array}{l}\text { Navigation between educational portal pages is } \\
\text { easy and clear. }\end{array}$ & $.500\left({ }^{*} *\right)$ & $\begin{array}{l}\text { There is constant encouragement by the } \\
\text { school administration to activate the } \\
\text { educational portal. }\end{array}$ & $.363\left({ }^{* * *}\right)$ \\
\hline $\begin{array}{l}\text { The educational portal allows the use of photos } \\
\text { and videos in educational activities. }\end{array}$ & $.666\left(^{* * *}\right)$ & $\begin{array}{l}\text { Guides for teachers explain how to use } \\
\text { the-learning Portal. }\end{array}$ & $.287\left({ }^{* * *}\right)$ \\
\hline $\begin{array}{l}\text { All contents of the educational portal are } \\
\text { necessary and indispensable. }\end{array}$ & $.656\left(^{(* *}\right)$ & $\begin{array}{l}\text { The educational portal provides an } \\
\text { opportunity for self-learning for students } \\
\text { beyond the boundaries of time and space. }\end{array}$ & $.360\left({ }^{* * *}\right)$ \\
\hline
\end{tabular}

\section{Results and Discussions}

3.1. Results Related to the First Question

To answer the first question, what is the degree of educational portal use as a system for managing elearning in His Majesty King Hamad's project for future schools from its teachers' perspective?

In answering that question, the researcher calculated the arithmetic averages, standard deviations and the relative arrangement of the degree of educational portal use as a system for managing e-learning in His Majesty King Hamad's project for future schools from its teachers' perspective, as shown in Table 5:

Table-5. Averages and standard deviations of the first field "The degree of educational portal use in the future schools from its teachers' perspective ", sorted in descending order.

\begin{tabular}{|c|c|c|c|c|c|}
\hline No & Order by & Item & Mean & SD & Level \\
\hline 12 & 1 & $\begin{array}{l}\text { Adding the weekly newsletter to the subjects to } \\
\text { be learned for various subjects. }\end{array}$ & 4.194 & .6853 & Large \\
\hline 4 & 2 & Download textbooks for various subjects. & 4.118 & .8224 & Large \\
\hline 11 & 3 & Adding the weekly study schedule for subjects. & 4.029 & .8123 & Large \\
\hline 17 & 4 & Modify and update user profile. & 3.944 & .6912 & Large \\
\hline 7 & 5 & $\begin{array}{l}\text { Add training activities for students to the } \\
\text { subjects studied. }\end{array}$ & 3.844 & .6800 & Large \\
\hline 6 & 6 & Add e-lessons for various subjects. & 3.835 & .7541 & Large \\
\hline 3 & 7 & $\begin{array}{l}\text { Read circulars and internal communications } \\
\text { issued by the school administration. }\end{array}$ & 3.824 & .7514 & Large \\
\hline 16 & 8 & $\begin{array}{l}\text { Communicate with the school portal } \\
\text { administrator to solve technical problems. }\end{array}$ & 3.824 & .7746 & Large \\
\hline 2 & 9 & $\begin{array}{l}\text { See the calendar and its announcements and } \\
\text { bulletins. }\end{array}$ & 3.776 & .7777 & Large \\
\hline 5 & 10 & $\begin{array}{l}\text { Download educational guides for various } \\
\text { educational stages. }\end{array}$ & 3.753 & .8575 & Large \\
\hline 1 & 11 & See instructions from the school administration. & 3.726 & .7825 & Large \\
\hline 15 & 12 & $\begin{array}{l}\text { Communicate with students and their parents } \\
\text { regarding the educational process. }\end{array}$ & 3.679 & .7368 & Large \\
\hline 13 & 13 & $\begin{array}{l}\text { Publish special announcements by the teacher } \\
\text { regarding the educational process. }\end{array}$ & 3.653 & .7739 & Medium \\
\hline 9 & 14 & $\begin{array}{l}\text { Providing educational enrichments in various } \\
\text { subjects. }\end{array}$ & 3.606 & .8202 & Medium \\
\hline 8 & 15 & $\begin{array}{l}\text { Add discussion panels for students to the topics } \\
\text { learned. }\end{array}$ & 3.585 & .7575 & Medium \\
\hline 10 & 16 & $\begin{array}{l}\text { Add projects and educational experiences for } \\
\text { various subjects. }\end{array}$ & 3.412 & .8764 & Medium \\
\hline 14 & 17 & $\begin{array}{l}\text { Monitor the attendance and absence of students } \\
\text { for different grades. }\end{array}$ & 3.274 & .8983 & Medium \\
\hline & & Total Summation & 3.702 & .3538 & Large \\
\hline
\end{tabular}


Table 5 shows the arithmetic averages and the standard deviations for the degree of educational portal use as a system for managing e-learning in the schools of His Majesty King Hamad's project for future schools from its teachers' perspective. It is noted that the overall mean of teachers 'estimates for the items' scale was (3.702) and a standard deviation was (.3538). The teachers 'estimates for the degree of educational portal use in the educational process were "high" for sorted items (1-12) and obtained arithmetic averages ranging from (4.194-3.679) and standard deviations ranging from (.7368-.6853). item 1 ("Adding the weekly newsletter to the subjects to be learned for various subjects") got the highest arithmetic average of 4,194 and a standard deviation of (6853.), while item 12 ("Communicate with students and their parents regarding the educational process") obtained the lowest mean of $(3,679)$ and a standard deviation of $(7,368)$. The reason for this is that one of the main goals of the educational portal is to help teachers manage e-learning, save time and effort in the-learning process, and communicate with students and parents. All these reasons led teachers to use the educational portal in a significant way in the-learning process due to the programs and services provided by the educational portal in the field of e-learning management. Likewise, the Ministry of Education in the Kingdom of Bahrain is keen to employ the educational portal in the-learning process by holding training courses for teachers that enable them to use the educational portal in an optimal way in the-learning process. This is confirmed by the study of Mahmud et al. (2012); Al-Hinai (2011) as the results of these studies indicated that the use of the educational portal was largely in the educational process, especially in the field of school administration.

The teachers 'estimates came towards the degree of educational portal use in future schools with a moderate degree for the sorted items (13-17), and obtained arithmetic averages ranging from (3.274-3.653) and standard deviations ranging from (.8983-.7739). Item 13 (Publish special announcements by the teacher regarding the educational process) got the highest arithmetic average of (3.653) and a standard deviation of (.7368), while item 14 (Monitor the attendance and absence of students for different grades) obtained the lowest mean of (3.274) and a standard deviation of (.8983). The reason for this is that monitoring attendance and absence in some schools is mostly within the responsibility of the school's administrative supervision and not within the scope of the teacher's responsibility. In addition, the preparation of educational projects and teacher preparation experiences requires teachers to have sufficient experience in preparing and implementing them, especially as it is one of the pioneering projects in the field of learning that requires teacher preparation in advance and continuous teacher-training programs in using them. The lack of communication between teachers and students outside of school hours also limits the addition of discussion sessions by the teacher to communicate with students on the topics that have been learned. The lack of communication between teachers and parents through the educational portal limits the publication of advertisements by the teacher and the occasional restriction of publishing advertisements through paper or text messages over the phone. This is confirmed by research like those by Mahmud et al. (2012); Al-Sawaei (2010).

\subsection{Results Related to the Second Question}

To answer the second question (What are teachers' perceptions of using the educational portal as a system for managing e-learning in His Majesty King Hamad's Project for Future Schools?)

To answer this question, the researcher calculated the arithmetic averages, standard deviations and the relative arrangement of teachers' perceptions of using the educational portal as an e-learning management system in His Majesty King Hamad's project for future schools from its teachers', as shown in Table 6.

Table 6 shows the arithmetic averages and the standard deviations for teachers' perceptions towards the educational portal use as an e-learning management system in His Majesty King Hamad's project for future schools. The mean of teachers' perceptions towards the educational portal use as an e-learning management system were "high" for sorted items (1-10) and obtained arithmetic averages ranging from (3.671-3.932) and standard deviations ranging from (.7632-3.932). item 5 ("All contents of the educational portal are necessary and irreplaceable") got the highest arithmetic average of $(3,932)$ and a standard deviation of $(.7632)$, while item 9 ("The Ministry provides adequate training on the use of the educational portal") obtained the lowest mean of $(3,671)$ and a standard deviation of $(.8976)$.

The reason is attributed to the great effort made by the Ministry of Education in the Kingdom of Bahrain in designing the educational portal through the use of various expertise locally and globally. The Ministry also linked the site with the Systems Department of the Ministry, where specialists and technicians solve technical and technical problems facing users in the educational portal, whether they are teachers, students or parents, as well as working to modify and develop it continuously, and to provide a high level of protection and security for users of the educational portal.

There are many studies that agreed with the results of this study like those by Pynoo and van Braak (2014); Mahmud et al. (2012); Hsia and Tseng (2016); Dakhil (2014) which indicated that teachers' attitudes have been positive towards using the educational portal in the educational process and has a major role in improving it Issham et al. (2010) confirmed that the design of the educational portal, its façade, font size and portal language, have a major impact on beneficiaries' satisfaction and interaction with the portal. 
Table-6. Averages and standard deviations of the second field "Teachers' perceptions towards the educational portal in the future schools", sorted in descending order.

\begin{tabular}{|c|c|c|c|c|c|}
\hline No & Order by & Item & Mean & SD & Level \\
\hline 3 & 1 & $\begin{array}{l}\text { There is harmony and consonance between the educational } \\
\text { portal background and the colours and fonts used. }\end{array}$ & 3.932 & .7632 & Large \\
\hline 1 & 2 & $\begin{array}{l}\text { The contents of the educational portal are visible on the } \\
\text { home page. }\end{array}$ & 3.879 & .6741 & Large \\
\hline 6 & 3 & The educational portal is in continuous development. & 3.829 & .7721 & Large \\
\hline 2 & 4 & $\begin{array}{l}\text { Navigating between pages of the educational portal is easy } \\
\text { and clear. }\end{array}$ & 3.809 & .7956 & Large \\
\hline 8 & 5 & $\begin{array}{l}\text { There is constant encouragement by the school } \\
\text { administration to activate the educational portal. }\end{array}$ & 3.779 & .8173 & Large \\
\hline 7 & 6 & $\begin{array}{l}\text { All components of the educational portal have a high level } \\
\text { of protection and privacy. }\end{array}$ & 3.776 & .7348 & Large \\
\hline 11 & 7 & $\begin{array}{l}\text { The educational portal provides an opportunity for students } \\
\text { to self-learn beyond the limits of time and space. }\end{array}$ & 3.703 & .7852 & Large \\
\hline 4 & 8 & $\begin{array}{l}\text { The educational portal allows the use of images and video } \\
\text { clips in educational activities. }\end{array}$ & 3.697 & .8052 & Large \\
\hline 5 & 9 & $\begin{array}{l}\text { All contents of the educational portal are necessary and } \\
\text { irreplaceable. }\end{array}$ & 3.671 & .8976 & Large \\
\hline 9 & 10 & $\begin{array}{l}\text { The Ministry provides adequate training on the use of the } \\
\text { educational portal. }\end{array}$ & 3.650 & .7591 & Medium \\
\hline 12 & 11 & $\begin{array}{l}\text { Technical support is available at the school to solve } \\
\text { technical problems related to the educational portal. }\end{array}$ & 3.518 & .8873 & Medium \\
\hline 10 & 12 & $\begin{array}{l}\text { The availability of guidelines for teachers that explain how } \\
\text { to use the educational portal. }\end{array}$ & 3.182 & ..9635 & Medium \\
\hline & & Total summation & 3.702 & .3538 & Large \\
\hline
\end{tabular}

The perceptions of teachers came towards using the educational portal as a system for managing elearning with a medium degree for the sorted items (10-12). They obtained mathematical averages ranging between (3.182-3.650) and standard deviations ranging from (7591.- 9635). Item 9 (The Ministry provides adequate training in the use of the educational portal) got the highest arithmetic average of $(3,650)$ and a standard deviation of (.7591), while item 10 ("The availability of guidelines for teachers that explain how to use the educational portal") got the lowest arithmetic average of 3.182 and a standard deviation of (.9635). The reason is attributed to the lack of specialists and technicians in some schools that are able to solve technical problems. Also, some technical problems require solving by the competent authorities in the Systems Department of the Ministry, which requires time to solve, in addition to the variation of teachers in training on the use of the educational portal in various aspects of the educational and administrative process. Also, The available guidelines that explain to users how to use the educational portal are prepared by technicians in schools and not by the competent authorities in the Ministry of Education, which requires the systems administration to prepare a comprehensive and detailed guide that explains to all users (school administrations, teachers, students, parents) how to use all programs and use them in the educational process.

\subsection{Results Related to the Third Question}

To answer the third question (Are there statistically significant differences at the level of significance $(\alpha \leq$ 0.05) to the degree of use for the educational portal as a system for e-learning management in His Majesty King Hamad's project for schools of the future according to the difference of gender variable, qualification variable, variable of experience in teaching, training courses variable, and interaction between them?).

To answer this question, the researcher calculated the arithmetic averages, standard deviations of the sample estimates towards the use of the educational portal as an e-learning management system in His Majesty King Hamad's project for future schools according to the difference of gender variable, qualification variable, variable of experience in teaching, training courses variable. Table 7 illustrates this point.

It is clear from Table 7 that there are apparent differences between the averages of the estimates of the sample for the degree of educational portal use as a system for managing e-learning in future schools according to gender variable, qualification variable, variable of experience in teaching, training courses variable. To find out the statistical significance of these differences, quadratic variance analysis was used. 
Table-7. Averages and standard deviations of "Teachers' estimates towards the educational portal use according to gender, qualification, experience in teaching, training course.

\begin{tabular}{|c|c|c|c|c|c|c|c|c|c|c|c|}
\hline \multirow{3}{*}{$\begin{array}{l}\text { Edu } \\
\text { Oual }\end{array}$} & \multirow{3}{*}{$\begin{array}{l}\text { Exp. in } \\
\text { teaching }\end{array}$} & \multirow{3}{*}{$\begin{array}{l}\text { Training } \\
\text { Courses }\end{array}$} & \multicolumn{9}{|c|}{ Gender } \\
\hline & & & \multicolumn{3}{|c|}{ Female } & \multicolumn{3}{|l|}{ Male } & \multicolumn{3}{|c|}{ Grand total } \\
\hline & & & Mean & SD & No & Mean & SD & No & Mean & SD & No. \\
\hline \multirow{16}{*}{$\begin{array}{l}\frac{\dot{0}}{0} \\
\frac{0}{0} \\
\stackrel{\Xi}{0}\end{array}$} & \multirow{4}{*}{$\begin{array}{l}\text { Less than } \\
5 \text { years }\end{array}$} & $\begin{array}{l}\text { Not } \\
\text { attending } \\
\text { courses }\end{array}$ & 3.739 & .3355 & 4 & 3.857 & .2469 & 7 & 3.790 & .2968 & 11 \\
\hline & & $\begin{array}{ll}\text { From } & 1-3 \\
\text { courses } & \end{array}$ & 3.638 & .5274 & 11 & 4.049 & .3874 & 6 & 3.703 & .5258 & 17 \\
\hline & & $\begin{array}{l}\text { More than } 3 \\
\text { courses }\end{array}$ & 3.912 & .1556 & 7 & 3.894 & .3539 & 5 & 3.902 & .2680 & 12 \\
\hline & & Total & 3.682 & .4743 & 22 & 3.931 & .3204 & 18 & 3.754 & .4480 & 40 \\
\hline & \multirow{4}{*}{$\begin{array}{l}\text { From 5- } \\
10 \text { years }\end{array}$} & $\begin{array}{l}\text { Not } \\
\text { attending } \\
\text { courses }\end{array}$ & 3.703 & .4316 & 9 & 3.862 & .3552 & 6 & 3.711 & .4225 & 15 \\
\hline & & $\begin{array}{ll}\text { From } & 1-3 \\
\text { courses } & \\
\end{array}$ & 3.806 & .3943 & 14 & 3.796 & .3198 & 12 & 3.804 & .3763 & 26 \\
\hline & & $\begin{array}{l}\text { More than } 3 \\
\text { courses }\end{array}$ & 4.196 & .4454 & 7 & 3.825 & .3318 & 11 & 4.196 & .4454 & 18 \\
\hline & & Total & 3.794 & .4116 & 30 & 3.801 & .3097 & 29 & 3.795 & .3939 & 59 \\
\hline & \multirow{4}{*}{$\begin{array}{l}\text { More } \\
\text { than } 10 \\
\text { years }\end{array}$} & $\begin{array}{l}\text { Not } \\
\text { attending } \\
\text { courses }\end{array}$ & 3.667 & .4273 & 25 & 3.770 & .3640 & 11 & 3.697 & .4079 & 36 \\
\hline & & $\begin{array}{l}\text { From } 1-3 \\
\text { courses }\end{array}$ & 3.710 & .4834 & 21 & 3.649 & .4364 & 17 & 3.683 & .4618 & 38 \\
\hline & & $\begin{array}{l}\text { More than } 3 \\
\text { courses }\end{array}$ & 3.613 & .1947 & 12 & 4.059 & .2663 & 10 & 3.799 & .3147 & 22 \\
\hline & & Total & 3.687 & .4438 & 58 & 3.715 & .4210 & 38 & 3.698 & .4337 & 96 \\
\hline & \multirow{4}{*}{$\begin{array}{l}\text { Grand } \\
\text { total }\end{array}$} & $\begin{array}{l}\text { Not } \\
\text { attending } \\
\text { courses }\end{array}$ & 3.691 & .4096 & 38 & 3.808 & .3099 & 24 & 3.721 & .3882 & 62 \\
\hline & & $\begin{array}{ll}\text { From } & 1-3 \\
\text { courses } & \\
\end{array}$ & 3.730 & .4635 & 46 & 3.731 & .4170 & 35 & 3.730 & .4488 & 81 \\
\hline & & $\begin{array}{l}\text { More than } 3 \\
\text { courses }\end{array}$ & 3.824 & .3344 & 26 & 3.976 & .3078 & 26 & 3.887 & .3259 & 52 \\
\hline & & Total & 3.726 & .4403 & 110 & 3.777 & .3885 & 85 & 3.741 & .4254 & 195 \\
\hline \multirow{12}{*}{ 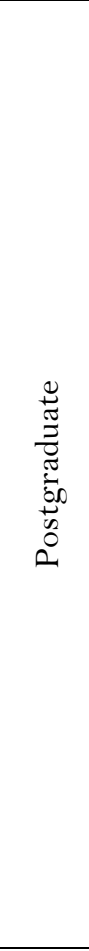 } & \multirow{4}{*}{$\begin{array}{l}\text { Less than } \\
5 \text { years }\end{array}$} & $\begin{array}{l}\text { Not } \\
\text { attending } \\
\text { courses }\end{array}$ & 3.588 & .3424 & 7 & 3.804 & .3019 & 8 & 3.750 & .2690 & 15 \\
\hline & & $\begin{array}{ll}\text { From } & 1-3 \\
\text { courses } & \\
\end{array}$ & 3.956 & .1944 & 10 & 3.735 & .4544 & 9 & 3.846 & .3443 & 19 \\
\hline & & $\begin{array}{l}\text { More than } 3 \\
\text { courses }\end{array}$ & 3.867 & .2211 & 9 & 4.941 & .4154 & 7 & 4.941 & .4544 & 16 \\
\hline & & Total & 3.882 & .2353 & 26 & 3.912 & .5373 & 24 & 3.900 & .4325 & 50 \\
\hline & \multirow{4}{*}{$\begin{array}{l}\text { From 5- } \\
10 \text { years }\end{array}$} & $\begin{array}{l}\text { Not } \\
\text { attending } \\
\text { courses }\end{array}$ & 3.863 & .2080 & 7 & 3.647 & .0832 & 9 & 3.750 & .1757 & 16 \\
\hline & & $\begin{array}{ll}\text { From } & 1-3 \\
\text { courses } & \\
\end{array}$ & 4.002 & .3902 & 8 & 4.667 & .6037 & 11 & 4.286 & .5697 & 19 \\
\hline & & $\begin{array}{l}\text { More than } 3 \\
\text { courses }\end{array}$ & 3.947 & .3637 & 7 & 4.471 & .5514 & 8 & 4.471 & .3164 & 15 \\
\hline & & Total & 3.951 & .3252 & 22 & 4.294 & .6357 & 28 & 4.123 & .5137 & 50 \\
\hline & \multirow{4}{*}{$\begin{array}{l}\text { More } \\
\text { than } 10 \\
\text { years }\end{array}$} & $\begin{array}{l}\text { Not } \\
\text { attending } \\
\text { courses }\end{array}$ & 3.676 & .8735 & 6 & 3.790 & .2839 & 7 & 3.765 & .3979 & 13 \\
\hline & & $\begin{array}{ll}\text { From } & 1-3 \\
\text { courses } & \\
\end{array}$ & 3.869 & .2938 & 9 & 3.635 & .4696 & 10 & 3.746 & .4038 & 19 \\
\hline & & $\begin{array}{l}\text { More than } 3 \\
\text { courses }\end{array}$ & 3.827 & .5741 & 7 & 4.608 & .6290 & 6 & 4.608 & .6290 & 13 \\
\hline & & Total & 3.834 & .3891 & 22 & 3.835 & .5363 & 23 & 3.835 & .4823 & 45 \\
\hline
\end{tabular}




\begin{tabular}{|c|c|c|c|c|c|c|c|c|c|c|c|}
\hline & \multirow{4}{*}{$\begin{array}{l}\text { Grand } \\
\text { total }\end{array}$} & $\begin{array}{l}\text { Not } \\
\text { attending } \\
\text { courses }\end{array}$ & 3.729 & .4643 & 20 & 3.770 & .2539 & 24 & 3.758 & .3140 & 44 \\
\hline & & $\begin{array}{ll}\begin{array}{l}\text { From } \\
\text { courses }\end{array} & 1-3 \\
\end{array}$ & 3.920 & .2866 & 27 & 3.841 & .6045 & 30 & 3.881 & .4676 & 57 \\
\hline & & $\begin{array}{l}\text { More than } 3 \\
\text { courses }\end{array}$ & 3.871 & .3891 & 23 & 4.647 & .4779 & 21 & 4.647 & .4779 & 44 \\
\hline & & Total & 3.877 & .3322 & 70 & 3.934 & .5636 & 75 & 3.912 & .4833 & 145 \\
\hline & \multirow{4}{*}{$\begin{array}{l}\text { Less } \\
\text { than } \\
5 \text { years }\end{array}$} & $\begin{array}{l}\text { Not } \\
\text { attending } \\
\text { courses }\end{array}$ & 3.724 & .3199 & 11 & 3.841 & .2481 & 15 & 3.782 & .2851 & 26 \\
\hline & & $\begin{array}{ll}\begin{array}{l}\text { From } \\
\text { courses }\end{array} & 1-3 \\
\end{array}$ & 3.673 & .5098 & 21 & 3.924 & .4224 & 15 & 3.728 & .4987 & 36 \\
\hline & & $\begin{array}{l}\text { More than } 3 \\
\text { courses }\end{array}$ & 3.912 & .1556 & 16 & 4.069 & .5319 & 12 & 4.006 & .4145 & 28 \\
\hline & & Total & 3.702 & .4585 & 48 & 3.925 & .3883 & 42 & 3.779 & .4460 & 90 \\
\hline & \multirow{4}{*}{$\begin{array}{l}\text { From } \\
5-10 \\
\text { years }\end{array}$} & $\begin{array}{l}\text { Not } \\
\text { attending } \\
\text { courses }\end{array}$ & 3.717 & .4154 & 16 & 3.725 & .1480 & 15 & 3.718 & .3909 & 31 \\
\hline & & $\begin{array}{ll}\begin{array}{l}\text { From } \\
\text { courses }\end{array} & 1-3 \\
\end{array}$ & 3.820 & .3937 & 22 & 3.941 & .4884 & 23 & 3.850 & .4187 & 45 \\
\hline & & $\begin{array}{l}\text { More than } 3 \\
\text { courses }\end{array}$ & 4.196 & .4454 & 14 & 4.471 & .4541 & 19 & 4.265 & .3887 & 33 \\
\hline & & Total & 3.806 & .4062 & 52 & 3.936 & .4639 & 57 & 3.834 & .4203 & 109 \\
\hline & & $\begin{array}{l}\text { Not } \\
\text { attending } \\
\text { courses }\end{array}$ & 3.667 & .4436 & 31 & 3.778 & .3263 & 18 & 3.710 & .4026 & 49 \\
\hline & than & $\begin{array}{ll}\begin{array}{l}\text { From } \\
\text { courses }\end{array} & 1-3 \\
\end{array}$ & 3.736 & .4594 & 30 & 3.646 & .4385 & 27 & 3.695 & .4501 & 57 \\
\hline & 10 years & $\begin{array}{l}\text { More than } 3 \\
\text { courses }\end{array}$ & 3.613 & .1947 & 19 & 4.265 & .4841 & 16 & 3.961 & .4965 & 35 \\
\hline & & Total & 3.705 & .4383 & 80 & 3.749 & .4556 & 61 & 3.724 & .4451 & 141 \\
\hline & \multirow{4}{*}{ Total } & $\begin{array}{l}\text { not } \\
\text { attending } \\
\text { courses }\end{array}$ & 3.694 & .4102 & 58 & 3.793 & .2857 & 48 & 3.728 & .3742 & 106 \\
\hline \multirow{3}{*}{ 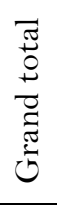 } & & $\begin{array}{ll}\begin{array}{l}\text { From } \\
\text { courses }\end{array} & 1-3 \\
\end{array}$ & 3.752 & .4500 & 73 & 3.757 & .4650 & 65 & 3.754 & .4540 & 138 \\
\hline & & $\begin{array}{l}\text { More than } 3 \\
\text { courses }\end{array}$ & 3.824 & .3344 & 49 & 4.200 & .4829 & 47 & 4.018 & .4530 & 96 \\
\hline & & Total & 3.741 & .4325 & 180 & 3.822 & .4487 & 160 & 3.769 & .4393 & 340 \\
\hline
\end{tabular}

Table-8. ANOVA of the significance of the differences in teachers 'estimates towards the degree of educational portal use according variables gender, qualification, experience in teaching, training course, and the interaction between them.

\begin{tabular}{|c|c|c|c|c|c|}
\hline Variables & $\begin{array}{l}\text { Sum of } \\
\text { squares }\end{array}$ & $\begin{array}{l}\text { Deg. of } \\
\text { freedom }\end{array}$ & Avg. of squares & $\begin{array}{c}\mathbf{F} \\
\text { value }\end{array}$ & Sig. \\
\hline Gender & .162 & 1 & .162 & .895 & .345 \\
\hline Qual. & 1.635 & 1 & 1.635 & 9.044 & .003 \\
\hline Exp. in teaching & .894 & 2 & .447 & 2.472 & .086 \\
\hline Training courses & 3.077 & 2 & 1.539 & 8.511 & .000 \\
\hline Gender* Qual. & .051 & 1 & .051 & .282 & .596 \\
\hline Gender*Exp. in teaching & .184 & 2 & .092 & .508 & .602 \\
\hline Gender* training courses & .144 & 2 & .072 & .397 & .673 \\
\hline Qual.* Exp. in teaching & .241 & 2 & .120 & .667 & .514 \\
\hline Qual.* training courses & 1.154 & 2 & .577 & 3.192 & .042 \\
\hline Exp. in teaching* training courses & .331 & 4 & .083 & .458 & .767 \\
\hline Error & 57.846 & 320 & .181 & & \\
\hline Grand total & 65.426 & 339 & & & \\
\hline
\end{tabular}

Table 8 shows that there are no statistically significant differences at $(\alpha \leq 0.05)$ between the estimates of the sample for the degree of educational portal use as a system for managing e-learning in future schools due to the gender variable and variable of experience in teaching. The researcher attributes this to the fact that the 
educational portal system is a unified system for all schools, which requires school administrations to follow all teachers to employ the educational portal in the e-learning department by following the same instructions and methods used in employing them. In addition, the Ministry is keen to hold training courses for teachers on how to make optimum use of them. Teaching experience also does not play a fundamental role in providing teachers with the ability to employ the educational portal in e-learning management, as these systems are new and teachers have not been trained to them. The Ministry is also keen to train all teachers, regardless of teaching experience. In addition teachers' awareness of their different experiences, they should have been aware of the necessity of employing the educational portal in managing e-learning and realizing its importance in facilitating the process of communication between teachers, students and parents regarding the educational process. This is confirmed by the Al-Sawaei (2010) that there are no statistically significant differences in the responses of the sample due to the gender variable, while there are statistically significant differences attributed to the variable of experience.

There are statistically significant differences at the significance level of $(\alpha \leq 0.05)$ due to the variables of qualification, training courses, and the interaction between them. This is confirmed by research like those by Mahmud et al. (2012); Ameri (2010). The researchers concluded that some teachers lack the skills to make the best use of the advantages the educational portal provides, which requires the ministry to train teachers to use it. This confirms that the training courses contribute significantly to employing the educational portal in an optimal way. On a similar note, this study differs from that of Al-Sawaei (2010) in that there were no statistically significant differences in the responses of the sample due to the variable of the qualification.

\subsection{Results Related to the Fourth Question}

To answer the fourth question (Are there statistically significant differences at the level of significance $(\alpha \leq 0.05)$ of teachers 'perceptions towards the use of the educational portal as an e-learning management system in His Majesty King Hamad's project for future schools according to the difference of gender variable, qualification variable, variable of experience in teaching, training courses variable, and interaction between them?

The researcher calculated the arithmetic averages and the standard deviations of teachers' perceptions towards using the educational portal as a system for managing e-learning in future schools according to the difference variables of gender, qualification, experience in teaching, and training courses. Table 9 illustrates this point.

Table-9. Averages and standard deviations of "Teachers' perceptions towards the educational portal use according to the difference variables gender, qualification, experience in teaching, and training course.

\begin{tabular}{|c|c|c|c|c|c|c|c|c|c|c|c|}
\hline \multirow{3}{*}{ 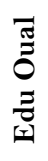 } & \multirow{3}{*}{$\begin{array}{l}\text { Exp. in } \\
\text { teaching }\end{array}$} & \multirow{3}{*}{$\begin{array}{l}\text { Training } \\
\text { courses }\end{array}$} & \multicolumn{9}{|c|}{ Gender } \\
\hline & & & \multicolumn{3}{|c|}{ Female } & \multicolumn{3}{|c|}{ Male } & \multicolumn{3}{|c|}{ Grand total } \\
\hline & & & Mean & SD & No & Mean & SD & No & Mean & SD & No. \\
\hline \multirow{15}{*}{$\frac{\frac{\check{0}}{\circlearrowright}}{\frac{\tilde{J}}{\tilde{U}}}$} & \multirow{4}{*}{$\begin{array}{l}\text { Less than } \\
5 \text { years }\end{array}$} & $\begin{array}{l}\text { Not attending } \\
\text { courses }\end{array}$ & 3.676 & .2583 & 4 & 3.583 & .2764 & 7 & 3.635 & .2615 & 11 \\
\hline & & $\begin{array}{ll}\begin{array}{l}\text { From } \\
\text { courses }\end{array} & 1-3 \\
\end{array}$ & 3.638 & .4294 & 11 & 3.847 & .4516 & 6 & 3.671 & .4336 & 17 \\
\hline & & $\begin{array}{l}\text { More than } 3 \\
\text { courses }\end{array}$ & 3.833 & .3118 & 7 & 3.717 & .1728 & 5 & 3.769 & .2349 & 12 \\
\hline & & Total & 3.663 & .3896 & 22 & 3.708 & .3275 & 18 & 3.676 & .3709 & 40 \\
\hline & \multirow{4}{*}{$\begin{array}{l}\text { From } \\
5-10 \text { years }\end{array}$} & $\begin{array}{l}\text { Not attending } \\
\text { courses }\end{array}$ & 3.696 & .3836 & 9 & 3.583 & .3861 & 6 & 3.690 & .3747 & 15 \\
\hline & & $\begin{array}{ll}\begin{array}{l}\text { From } \\
\text { courses }\end{array} & 1-3 \\
\end{array}$ & 3.727 & .3571 & 14 & 3.684 & .3358 & 12 & 3.720 & .3501 & 26 \\
\hline & & $\begin{array}{l}\text { More than } 3 \\
\text { courses }\end{array}$ & 3.750 & .3005 & 7 & 3.691 & .3372 & 11 & 3.750 & .3005 & 18 \\
\hline & & Total & 3.720 & .3583 & 30 & 3.687 & .3256 & 29 & 3.714 & .3511 & 59 \\
\hline & \multirow{4}{*}{$\begin{array}{l}\text { More than } \\
10 \text { years }\end{array}$} & $\begin{array}{l}\text { Not attending } \\
\text { courses }\end{array}$ & 3.701 & .2747 & 25 & 3.795 & .2919 & 11 & 3.728 & .2792 & 36 \\
\hline & & $\begin{array}{ll}\begin{array}{l}\text { From } \\
\text { courses }\end{array} & 1-3 \\
\end{array}$ & 3.764 & .3193 & 21 & 3.695 & .3078 & 17 & 3.735 & .3143 & 38 \\
\hline & & $\begin{array}{l}\text { More than } 3 \\
\text { courses }\end{array}$ & 3.702 & .1725 & 12 & 3.367 & .1918 & 10 & 3.563 & .2439 & 22 \\
\hline & & Total & 3.738 & .2935 & 58 & 3.685 & .3119 & 38 & 3.717 & .3008 & 96 \\
\hline & \multirow{3}{*}{$\begin{array}{l}\text { Grand } \\
\text { total }\end{array}$} & $\begin{array}{l}\text { Not attending } \\
\text { courses }\end{array}$ & 3.695 & .3103 & 38 & 3.706 & .2905 & 24 & 3.698 & .3035 & 62 \\
\hline & & $\begin{array}{ll}\begin{array}{l}\text { From } \\
\text { courses }\end{array} & 1-3 \\
\end{array}$ & 3.718 & .3643 & 46 & 3.711 & .3287 & 35 & 3.716 & .3531 & 81 \\
\hline & & More than 3 & 3.750 & .2311 & 26 & 3.542 & .2523 & 26 & 3.663 & .2571 & 52 \\
\hline
\end{tabular}




\begin{tabular}{|c|c|c|c|c|c|c|c|c|c|c|c|}
\hline & & courses & & & & & & & & & \\
\hline & & Total & 3.714 & .3410 & 110 & 3.690 & .3141 & 85 & 3.707 & .3328 & 195 \\
\hline \multirow{16}{*}{ 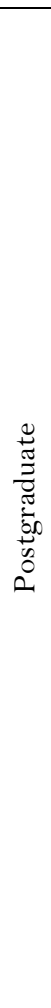 } & \multirow{4}{*}{$\begin{array}{l}\text { Less than } \\
5 \text { years }\end{array}$} & $\begin{array}{l}\text { Not attending } \\
\text { courses }\end{array}$ & 4.000 & .4141 & 7 & 3.583 & .3005 & 8 & 3.688 & .3219 & 15 \\
\hline & & $\begin{array}{ll}\begin{array}{l}\text { From } \\
\text { courses }\end{array} & 1-3 \\
\end{array}$ & 3.521 & .1049 & 10 & 3.375 & .5631 & 9 & 3.448 & .3830 & 19 \\
\hline & & $\begin{array}{l}\text { More than } 3 \\
\text { courses }\end{array}$ & 3.623 & .3412 & 9 & 4.583 & .3847 & 7 & 4.583 & .4004 & 16 \\
\hline & & Total & 3.617 & .2327 & 26 & 3.604 & .5735 & 24 & 3.609 & .4582 & 50 \\
\hline & \multirow{4}{*}{$\begin{array}{l}\text { From } \\
5 \text {-10 years }\end{array}$} & $\begin{array}{l}\text { Not attending } \\
\text { courses }\end{array}$ & 4.042 & .0589 & 7 & 3.917 & .5893 & 9 & 3.979 & .3494 & 16 \\
\hline & & $\begin{array}{ll}\begin{array}{l}\text { From } \\
\text { courses }\end{array} & 1-3 \\
\end{array}$ & 3.407 & .5314 & 8 & 3.611 & .7515 & 11 & 3.500 & .5833 & 19 \\
\hline & & $\begin{array}{l}\text { More than } 3 \\
\text { courses }\end{array}$ & 3.632 & .5237 & 7 & 3.750 & .3861 & 8 & 3.750 & 3.699 & 15 \\
\hline & & Total & 3.625 & .5237 & 22 & 3.736 & .5638 & 28 & 3.681 & .5220 & 50 \\
\hline & \multirow{4}{*}{$\begin{array}{l}\text { More than } \\
10 \text { years }\end{array}$} & $\begin{array}{l}\text { Not attending } \\
\text { courses }\end{array}$ & 3.760 & .1179 & 6 & 3.667 & .2453 & 7 & 3.685 & .2196 & 13 \\
\hline & & $\begin{array}{ll}\begin{array}{l}\text { From } \\
\text { courses }\end{array} & 1-3 \\
\end{array}$ & 3.667 & .5204 & 9 & 3.617 & .4029 & 10 & 3.640 & .4497 & 19 \\
\hline & & $\begin{array}{l}\text { More than } 3 \\
\text { courses }\end{array}$ & 3.673 & .3696 & 7 & 4.194 & .5549 & 6 & 4.194 & .5549 & 13 \\
\hline & & Total & 3.682 & .4682 & 22 & 3.721 & .4129 & 23 & 3.707 & .4259 & 45 \\
\hline & \multirow{4}{*}{$\begin{array}{l}\text { Grand } \\
\text { total }\end{array}$} & $\begin{array}{l}\text { Not attending } \\
\text { courses }\end{array}$ & 3.917 & .3667 & 20 & 3.688 & .3059 & 24 & 3.755 & .2879 & 44 \\
\hline & & $\begin{array}{ll}\begin{array}{l}\text { From } \\
\text { courses }\end{array} & 1-3 \\
\end{array}$ & 3.574 & .4496 & 27 & 3.559 & .4821 & 30 & 3.566 & .4591 & 57 \\
\hline & & $\begin{array}{l}\text { More than } 3 \\
\text { courses }\end{array}$ & 3.631 & .4352 & 23 & 4.183 & .4909 & 21 & 4.183 & .4909 & 44 \\
\hline & & Total & 3.652 & .4254 & 70 & 3.696 & .4678 & 75 & 3.679 & .4482 & 145 \\
\hline \multirow{16}{*}{ 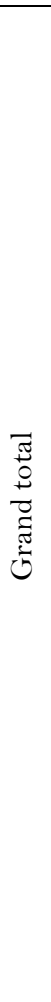 } & \multirow{4}{*}{$\begin{array}{l}\text { Less than } \\
5 \text { years }\end{array}$} & $\begin{array}{l}\text { Not attending } \\
\text { courses }\end{array}$ & 3.708 & .2643 & 11 & 3.583 & .2664 & 15 & 3.646 & .2661 & 26 \\
\hline & & $\begin{array}{ll}\begin{array}{l}\text { From } \\
\text { courses }\end{array} & 1-3 \\
\end{array}$ & 3.625 & .4070 & 21 & 3.658 & .5277 & 15 & 3.632 & .4298 & 36 \\
\hline & & $\begin{array}{ll}\begin{array}{l}\text { More than } 3 \\
\text { courses }\end{array} & \\
\end{array}$ & 3.833 & .3118 & 16 & 3.861 & .3861 & 12 & 3.850 & .3398 & 28 \\
\hline & & Total & 3.658 & .3754 & 48 & 3.676 & .4092 & 42 & 3.664 & .3847 & 90 \\
\hline & \multirow{4}{*}{$\begin{array}{l}\text { From } \\
5-10 \text { years }\end{array}$} & $\begin{array}{l}\text { Not attending } \\
\text { courses }\end{array}$ & 3.727 & .3790 & 16 & 3.806 & .4590 & 15 & 3.737 & .3794 & 31 \\
\hline & & $\begin{array}{ll}\begin{array}{l}\text { From } \\
\text { courses }\end{array} & 1-3 \\
\end{array}$ & 3.705 & .3747 & 22 & 3.681 & .4004 & 23 & 3.699 & .3785 & 45 \\
\hline & & $\begin{array}{l}\text { More than } 3 \\
\text { courses }\end{array}$ & 3.750 & .3005 & 14 & 3.750 & .4322 & 19 & 3.750 & .2453 & 33 \\
\hline & & Total & 3.713 & .3696 & 52 & 3.701 & .3897 & 57 & 3.710 & .3721 & 109 \\
\hline & \multirow{4}{*}{$\begin{array}{l}\text { More than } \\
10 \text { years }\end{array}$} & $\begin{array}{l}\text { Not attending } \\
\text { courses }\end{array}$ & 3.704 & .2659 & 31 & 3.745 & .2749 & 18 & 3.720 & .2672 & 49 \\
\hline & & $\begin{array}{ll}\begin{array}{l}\text { From } \\
\text { courses }\end{array} & 1-3 \\
\end{array}$ & 3.748 & .3555 & 30 & 3.678 & .3279 & 27 & 3.717 & .3435 & 57 \\
\hline & & $\begin{array}{l}\text { More than } 3 \\
\text { courses }\end{array}$ & 3.702 & .1725 & 19 & 3.677 & .5409 & 16 & 3.689 & .3990 & 35 \\
\hline & & Total & 3.731 & .3167 & 80 & 3.695 & .3407 & 61 & 3.715 & .3269 & 141 \\
\hline & \multirow{4}{*}{ Total } & $\begin{array}{l}\text { not attending } \\
\text { courses }\end{array}$ & 3.713 & .3064 & 58 & 3.699 & .2916 & 48 & 3.708 & .3000 & 106 \\
\hline & & $\begin{array}{ll}\begin{array}{l}\text { From } \\
\text { courses }\end{array} & 1-3 \\
\end{array}$ & 3.701 & .3764 & 73 & 3.676 & .3720 & 65 & 3.693 & .3743 & 138 \\
\hline & & $\begin{array}{l}\text { More than } 3 \\
\text { courses }\end{array}$ & 3.750 & .2311 & 49 & 3.756 & .4559 & 47 & 3.753 & .3588 & 96 \\
\hline & & Total & 3.708 & .3497 & 180 & 3.692 & .3625 & 160 & 3.702 & .3538 & 340 \\
\hline
\end{tabular}

It is clear from Table 9 that there are apparent differences between the averages of teachers' perceptions towards the use of the educational portal as a system for managing e-learning in future schools according to gender, qualification, experience in teaching, and training courses variables. Table 10 illustrates this point. 
Table-10. ANOVA of the significance of differences in teachers' perceptions towards educational portal use according to variables gender , qualification, experience in teaching, training courses, and the interaction between them.

\begin{tabular}{|c|c|c|c|c|c|}
\hline Variables & Sum of squares & $\begin{array}{l}\text { Deg. of } \\
\text { freedom }\end{array}$ & $\begin{array}{c}\text { Avg. } \\
\text { of squares }\end{array}$ & $\begin{array}{c}\mathbf{F} \\
\text { value }\end{array}$ & Sig. \\
\hline Gender & .333 & 1 & .333 & 2.707 & .101 \\
\hline Qual. & .868 & 1 & .868 & 7.061 & .008 \\
\hline Exp. in teaching & .029 & 2 & .014 & .116 & .890 \\
\hline Training courses & 1.552 & 2 & .776 & 6.313 & .002 \\
\hline Gender* Qual. & .051 & 1 & .051 & .417 & .519 \\
\hline Gender*Exp. in teaching & .055 & 2 & .028 & .224 & .799 \\
\hline Gender* training courses & .360 & 2 & .180 & 1.463 & .233 \\
\hline Qual.* Exp. in teaching & .030 & 2 & .015 & .122 & .885 \\
\hline Qual.* training courses & 2.313 & 2 & 1.157 & 9.407 & .000 \\
\hline Exp. in teaching* ${ }^{*}$ training courses & .581 & 4 & .145 & 1.181 & .319 \\
\hline Error & 39.344 & 320 & .123 & & \\
\hline Grand total & 65.426 & 339 & & & \\
\hline
\end{tabular}

Table 10 shows that there are no statistically significant differences at $(\alpha \leq 0.05)$ between teachers' perceptions towards educational portal use as a system for managing e-learning in future schools due to the gender variable and variable of experience in teaching. The researcher attributes this to the great effort the Ministry of Education in the Kingdom of Bahrain is doing in designing the educational portal site with the assistance of local and international experiences in website design, the keenness of specialists and technicians to solve technical problems to develop it continuously and provide a high level of protection, the Ministry's keenness to train teachers on how to use them in the educational process. The educational portal project is also considered a recent project based on the use of information and communications technology in Education that have not previously available. In addition, the use of the educational portal does not require teaching experience to deal with it.

There are statistically significant differences at the level of significance $(\alpha \leq 0.05)$ attributable to the variables of qualification, training courses, and the interaction between them. The reason is that training courses contribute significantly to improving the teachers' use of the educational portal to make the best use of the tools and services the educational portal provides. In addition, qualification contributes to increasing teachers' awareness of the importance of employing the educational portal in the-learning process, for its significant contribution to improving the outputs of the educational process and achieving an opportunity for self-learning for learners.

\section{Conclusion and Recommendations}

The results of the current research showed a high degree of the educational portal use as a system for managing e-learning in His Majesty King Hamad's project for schools of the future as well as teachers 'perceptions towards it. In addition, that there are statistically significant differences attributable to the variables of the educational qualification and training courses in the degree of the educational portal use as a system for managing e-learning as well as teachers' perceptions towards it. In light of the current research results, the researcher recommends the following:

- The necessity of holding more courses and training workshops on how to employ the educational portal in various educational and administrative aspects

- The necessity of providing teacher's Guides that explain how to use the educational portal in the educational process.

- Expanding the database in the educational portal to include all educational and administrative aspects in the-learning process.

- Conducting more studies and research in the Kingdom of Bahrain dealing with the reality of using the educational portal to know the obstacles facing teachers in its use.

\section{References}

Abu Rayan, M. A. (2017). Technical and technological difficulties facing faculty members in their use of the academic portal of Al-Quds Open University. Palestinian Journal of Open Education and E-Learning, 6(11), 33-50.

Al-Ameri, M. M. (2010). A proposed vision for the educational portal at the ministry of education in the Sultanate of Oman in accordance with contemporary educational needs and standards. Unpublished PHD, Arab Research and Studies Institute, Cairo.

Al-Hinai, K. N. (2011). The reality of employing the e-learning portal in the school administration in the Sultanate of Oman. Unpublished Master Thesis, University of Nizwa, Faculty of Science and Arts, Sultanate of Oman.

Al-Jerioui, S. S. (2014). Use of repositories of educational digital objects in the teaching practices of faculty members at the Faculty of Education, Princess Nourah Bint Abdulrahman University. International Specialized Educational Journal, 3(7), 133-114. 
Al-Sawaei, H. (2010). The degree of use of the e-learning portal and the difficulties faced by teachers of schools in the Governorate of Muscat. Unpublished Master Thesis, Yarmouk University, Jordan.

Amer, A. M. (2017). Digital learning elements: New education news and ideas of learning techniques, Retrieved from: https://www.new-educ.com/Digital-Learning-Elements.

Ameri, M. M. (2010). A proposed vision for the educational portal at the Ministry of Education in the Sultanate of Oman in accordance with contemporary educational needs and standards. Unpublished PHD, Arab Research and Studies Institute, Cairo.

Brian, H. (2005). Technical evaluation reports: Learning objects and instructional design. The International Review of Research in open and Distance Learning, 6(2), 1-7.

Dakhil, L. O. A. (2014). Urethrovaginal fistula: A rare complication of transurethral catheterization. Female Pelvic Medicine \& Reconstructive Surgery, 20(5), 293-294.Available at: https://doi.org/10.1097/spv.0000000000000054.

Hamayel, A., \& Hamayel, M. (2006). Obstacles facing full-time academic supervisors at al-quds Open University using the University academic portal. Al-Quds Open University Journal for Research and Studies, 8(October), 11-67.

Hsia, J. W., \& Tseng, A. H. (2016). The eeffects of general personality traits and cognitive beliefs on elementary school teachers'use of an educational Portal in Taiwan. International Journal of Organizational Innovation, 9(1), 54-62.

Issham, I., Ramli, A., Rosli, M., \& Idrus, R. (2010). Users satisfaction toward E-learning portal: The role of design. Malyasian Journal of Mobile Learning, 1(1), 61-68.

Mahmud, R., Ismail, M. A. H., Rahman, F. A., Kamarudin, N., \& Ruslan, A. R. (2012). Teachers' readiness in utilizing educational portal resources in teaching and learning. Procedia-Social and Behavioral Sciences, 64, 484491.Available at: https://doi.org/10.1016/j.sbspro.2012.11.057.

Miri, S. K., \& Sahu, N. (2019). Design and development of HSES knowledge portal. International Journal of Information and Computing Science, 6(2), 85-90.

Othman, M. T. (2010). Oman education portal: Towards a connected society. Journal of the American Academy of Science and Technology (Amarabac), 1(2), 101-112.

Pima, J. M. (2013). Challenges facing higher education institutions in Tanzania in using portals. The Accountancy and Business Review, 182, 25-35.

Pynoo, B., \& van Braak, J. (2014). Predicting teachers' generative and receptive use of an educational portal by intention, attitude and self-reported use. Computers in Human Behavior, 34, 315-322.Available at: https://doi.org/10.1016/j.chb.2013.12.024.

Sadiq, A. (2012). Applied international experiences in the effective use of the Internet from educational portals to digital repositories. Journal of Educational Development, Sultanate of Oman, 10(70), 48-54.

Salem, A. M. (2004). Educational technology and e-learning. Riyadh: Al-Rushd Library.

Zein, O. S. (2016). Transition to the digital learning era cognitive advancement or systematic decline. Paper presented at the Eleventh International Conference: Learning in the Era of Digital Technology, Scientific Research Generation Center, Tripoli. 